\title{
Neoliberal reforms and macroeconomic policy in Peru
}

\section{Oscar Dancourt}

Professor,

Department of Economics, Catholic University of Peru.
This article describes the neoliberal experiment of the 1990s in Peru, placing it in its historical context. The central hypothesis is that in that decade the Peruvian economy has lacked an operational system of monetary and fiscal policies capable of functioning without giving rise to serious disturbances in the level of economic activity. The monetary authorities do not possess the basic instruments which have been used in the past to handle adverse external shocks affecting the Peruvian economy, because of two structural reforms carried out in the financial field: the dollarization of the banking system and the opening-up of the capital account. The article consists of seven sections. It begins with a brief introduction (section I). It then describes the neoliberal experiment of the 1990s, placing it in its immediate historical context (section II); analyses the role which has been played by the growth strategy, the international economic situation and macroeconomic policy in the long-term performance of the Peruvian economy (section III); describes the way in which adverse external shocks were handled in the period from 1950 to 1975 (section IV); examines the evolution of macroeconomic policy in the 1990s, analysing its limitations (section V); illustrates these limitations in the light of recent macroeconomic experience (section VI), and ends with some conclusions (section VII). 


\section{I}

\section{Introduction}

The expansion of the Peruvian economy during the 1950s and part of the 1960s, on the basis of an almost pure primary-export growth strategy and a State ideology based on the Manchester School, was an anachronism compared with the Southern Cone countries of Latin America, which favoured import substitution and the original economic thinking of ECLAC.

It was only in the 1970 s that the country embarked on a real import substitution strategy, once again in the most uncompromising version of the entire continent. Naturally, it only began to export manufactures at quite a late date, at the end of the decade. With the external debt crisis, the whole story went into suspended animation, and then came hyperinflation.

The neoliberal reforms of the 1990s, carried out by the Fujimori administration, seek to put the clock back to the 1950 s in economic terms, returning to the primary-export model. The control of hyperinflation and the defeat of Sendero Luminoso are the main positive elements in this venture. Some also suggest that a third and by no means negligible positive feature is the authoritarian nature of the political regime.

There are also two negative elements in this venture. One is the tendency to adopt extreme ap- proaches, which is almost a tradition in Peru. The history of the last few years is marked by too many radical economic experiments, too many irreversible structural reforms. Its radicalism may be one of the negative features of this neoliberal reform process of the 1990s, among other reasons because it impedes adaptation to outside circumstances, which are always changing for an economy like that of Peru, and generally speaking the outside situation in the first half of the present decade was excessively favourable.

The second important negative aspect of the neoliberal reforms is connected with macroeconomic policy. In the past, the Peruvian economy has rarely qualified as a candidate for the select club of the best-run economies of Latin America, as Chile did after 1983 or as Colombia has also done, but on the other hand it did not display permanent or structural defects in its macroeconomic policy system, that is to say, in its fiscal and monetary policy system.

Today, however, the situation is different. As we shall see below, the present macroeconomic policy system suffers from severe limitations due to the financial liberalization process of the 1990s: i.e., the dollarization of the banking system and the opening of the capital account.

\section{II}

\section{The significance of the structural reforms of the 1990s}

The structural reforms applied by the Fujimori government have reintroduced a primary-export growth strategy similar to that which has prevailed in the Peruvian economy during most of its economic history. This seems to be the distinctive feature of the Peru-

$\square$ The author wishes to express his gratitude for the comments made by Waldo Mendoza, the assistance provided by Alejandro Olivares, and the financial support of the International Development Centre and the Canadian International Development Agency. vian version of neoliberalism, as compared with other similar experiments carried out in Latin America. ${ }^{1}$

In order to understand the logic behind this return to the past, we will briefly review the economic growth of Peru from 1950 up to the present, set forth on the basis of two elements: first, identification of the periods through which the macroeconomic evolu-

\footnotetext{
${ }^{1}$ See Seminario (1995) and Schuldt (1994).
} 
FIGURE 1

Peru: Per capita gross domestic product, 1950-1997 (Indexes, 1979=100)

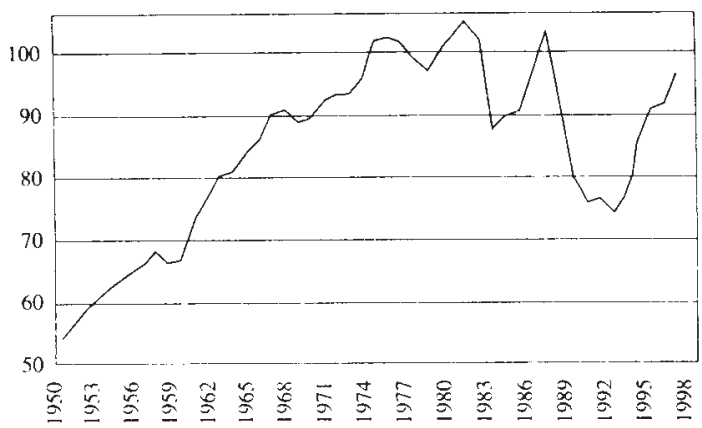

Source: Banco Central de Reserva del Perú.

tion of the country has passed in these 45 years and, second, a description of the main changes which have taken place in the growth strategy and the rate of investment in each of those periods.

As we may see from figure 1, three main stages may be distinguished in the long-term evolution of the per capita GDP. ${ }^{2}$ The first stage (1950-1975) was a period of rapid growth, interrupted by some brief recessions (in 1958-1959 and 1967-1969), with the per capita product growing at an average annual rate of $2.5 \%$. This first stage was also one of low inflation by Peruvian standards, with an average rate of $10 \%$ per year.

The second stage (1976-1990) may be described as a long-lasting crisis with violent cycles of booms and recessions; ${ }^{3}$ as may be seen from figure 1 , by the beginning of the 1990s the per capita product had dropped back to the level it had attained 30 years before. This was also a period of high inflation, culminating in the hyperinflation of 1988-1990, at the end of the Alan García administration (1985-1990); leaving out these last three years, average inflation stood at $83 \%$ per year. During the period of hyperinflation, price levels rose by a factor of 39 per year (4049\% per year), while the per capita product

\footnotetext{
${ }^{2}$ For a division into more detailed periods, see Vega-Centeno (1989).

3 Two important studies on the cycles and trends in the Peruvian economy during these 45 years (those by Seminario and Boullon (1992) and Robles (1996)) identify a structural turning point in the mid-1970s, after which the volatility of the macroeconomic aggregates substantially increased.
}

dropped by the unprecedented amount of almost onethird.

The third and final stage (1991-1997) represented a new period of stabilization and expansion in which the per capita product grew by over $3 \%$ per year, although without exceeding the maximum levels registered in the past. Inflation showed a clear downward tendency, standing at less than $10 \%$ per year at the end of this phase.

It may be emphasized that the development model or growth strategy which prevailed during much of the first stage and was marked by a combination of rapid growth and low inflation was an almost pure primary-export strategy.

This primary-export model, with a small State sector and the application of a policy of free trade, lasted in Peru until well into the 1960s. According to Thorp and Bertram (1978, part IV, Introduction), the Peruvian economy between 1948 and the late 1960s was the prime example in Latin America of that dream of orthodox developmentalists: an export-led system in which the entry of foreign capital and the repatriation of profits were virtually unrestricted and government intervention was kept to the minimum.

This Peruvian system was an anachronism in the Southern Cone of Latin America, ${ }^{4}$ where the prevailing model was based on import substitution industrialization, with protected domestic markets and relatively high rates of inflation, and the primaryexport sector was one of the least dynamic in the economy. ${ }^{5}$

The downfall of this primary-export model came in spite of its good macroeconomic performance. The crisis of the oligarchic State ${ }^{6}$ began quite late in Peru, during the first Belaúnde administration (1963-1968), which partly modified that model by embarking on a moderate policy of import substitution industrialization which attracted a certain amount of foreign investment. $^{7}$

\footnotetext{
${ }^{4}$ According to Borricaud (1989), the Peruvian oligarchy had learned how to maintain their dominant position in a world and a region where their foreign counterparts had already lost much of their former power.

${ }^{5}$ See Hofman, 1993.

${ }^{6}$ Cotler (1994) states that this crisis took place when political participation was spreading throughout the country to all levels of society, leading to the questioning of the structure of land ownership and the role of foreign capital, which were the pillars of the system of domination.

${ }^{7}$ Schydlowsky (1995) explains this by the fact that this industrialization began under a rather special combination of heavy tariff protection and weak "exchange-rate protection".
} 
Subsequently, under the military regime of General Velasco Alvarado (1968-1975), the primaryexport model ${ }^{8}$ really was replaced by import substitution industrialization. The industrialization strategy became more radical, both in terms of the degree of protection of the domestic market and the degree of State intervention in the economy. ${ }^{9}$ Through the nationalization of a considerable part of the foreignowned interests and the transfer to the State of part of the assets of the oligarchy, a strong public-enterprise sector was built up which came to control over $30 \%$ of GDP. According to Fitzgerald (1985), the State was responsible for three-quarters of exports, half of imports, more than half of fixed investment, two-thirds of bank credit and one-third of all employment in the entrepreneurial sector.

The other point that should be stressed, then, is that there were notable changes in the growth strategy during the first stage, which was marked by rapid growth and low inflation. This good macroeconomic performance was compatible both with the primaryexport model and with the import substitution model.

In the second stage, marked by persistent stagnation and high and growing inflation, no decisive changes were made in the development model imposed by the structural reforms of Velasco Alvarado. Two key features of this growth strategy persisted throughout these 15 years: the major role played by public enterprises and the heavy protection given to manufacturing.

There were two major attempts to change this development model, but both of them finally failed. The first was connected with the programme for the promotion of exports of manufactures applied in 1977-1980, while the main feature of the second was the trade openness of 1979-1982.

According to Schydlowsky (1986), the boom in non-traditional exports in 1977-1980 was attributable to the combination of substantial support for exports (an average of $27 \%$ of their FOB value), a devaluation of 28\% in real terms between 1976 and 1978, and a shrinking domestic market (which contracted by $20 \%$ or more between 1976 and 1978). In 1979, a new system of incentives for non-traditional products was

\footnotetext{
8 As noted by R. Thorp (1995, chapter IV) and Fitzgerald (1985), this new growth strategy did not, however, neglect the expansion of commodity exports.

9 See Thorp (1995), Fitzgerald (1985) and Schydlowsky and Wicht (1979).
}

introduced, with the undertaking that it would be kept unchanged for the next ten years. It was believed that the great moment for non-traditional exports had finally arrived. Nobody suspected at that time that the new civil government that would take office in mid1980 would reverse that policy before six months were out.

As well as doing away with this successful programme for the promotion of non-traditional exports, the second Belaúnde administration (1980-1985) further increased the trade openness ${ }^{10}$ begun in 1979 under the military regime of Morales Bermúdez (1976-1980) and generated a significant exchangerate lag. The 1982-1983 balance of payments crisis, associated with the onset of the external debt crisis, put an end to this first experiment in the liberalization of imports, which was the most direct forerunner of the neoliberal reforms of the 1990s.

In the third and last phase, under the Fujimori government, the growth strategy was once again radically altered. The structural reforms of the 1990s may be seen as the almost perfect antithesis to the reforms made under the Velasco Alvarado government (19681975), or alternatively as a new version of those made under the Odría government (1948-1956).

With the privatization of public enterprises and an extremely radical unilateral trade openness process, ${ }^{11}$ Peru returned in effect to the primary-export model of the 1950s. There was a marked decline in the importance of manufacturing, and whole branches of the industrial structure disappeared. An indicator of this process of de-industrialization was that while in 1995 the GDP finally recovered the absolute level that it had achieved in 1987, Peruvian manufacturing output ${ }^{12}$ was almost $20 \%$ smaller.

\footnotetext{
${ }^{10}$ See Ferrari (1992) and Rojas (1996).

11 The para-tariff protection system for manufacturing was totally dismantled and the system of cascading or stepped tariffs, so typical of import substitution industrialization, was replaced by a flat tariff along the lines of the Chilean system. Between 1990 and 1993, the average level of tariffs went down from 66\% to $16 \%$, and in $1993,98 \%$ of the total value of imports was subject to a tariff of 15\% (see Rojas, 1996; Ferrari, 1992; Rossini, 1991). Furthermore, Peru suspended its participation in the Andean Pact because of the stepped common tariff applied by that integration agreement (see Vega, 1997 and Fairlie, 1996).

12 Defined as the output of non-primary-commodity-based manufacturing industry, thus excluding the branches directly linked with the export of commodities (metal refining, production of fish meal, etc.). See, in this respect, Banco Central de Reserva del Perú (1996). With regard to de-industrialization, see Jiménez, 1996.
} 
Foreign capital, which went mainly to the export mining sector and public utilities, once again occupied a leading place in the economy, through the acquisition of many of the privatized State enterprises. ${ }^{13}$ The closure of almost the entire State development banking system, which played an important part in the loan and deposit markets, should also be included among the main reforms made in this period. ${ }^{14}$

It is interesting to compare the model imposed by Odría with that applied four decades later by Fujimori. Among their common features, González (1994) mentions the openness of the trade and capital accounts and a State which plays only a minimum part in the economy and encourages foreign investment, especially in the commodity export sector and public utilities, through very favourable legislation, while among the differences he notes that the public external debt now has significant weight in the fiscal and external sector accounts, unlike the earlier period.

In reality, the big difference is that real exports have not yet expanded by the required amount. The promise of a big expansion in mining exports in the second half of the 1990s had been made the theoretical base for the Fujimori growth model, but so far the real factor which has made economic growth possible between 1993 and 1995 has been the enormous inflow of capital (mostly short-term capital and inflows in respect of privatization operations), for which there is no precedent in the last 45 years.

One way of appreciating this difference is shown in figure 2, which highlights two facts. Firstly, that there was an alternation of deficits and surpluses in the trade balance during the Odría government, thus giving a balanced level on average, whereas during the Fujimori government the trade deficit is increasingly large: equivalent to $20 \%$ of annual exports on average. Secondly, that the trade balance and the for-

13 Between 1991 and 1993, the government obtained very little from the sale of public enterprises. Income from privatization operations became significant as from 1994, with the sale of 29 enterprises for an amount equivalent to $35 \%$ of annual central government tax revenue. In 1995, the sale of a further 28 enterprises and various other assets generated income equal to $12 \%$ of tax revenue. In 1996, the income from 28 privatization operations increased once again to the equivalent of $25 \%$ of tax revenue. In 1997, income from privatization operations went down by over $70 \%$ compared with the previous year, amounting to the equivalent of only $6 \%$ of tax revenue, and it was expected to go down still further in 1998. Only exceptionally has public external debt paper been accepted as a means of payment in the privatization process.

${ }^{14}$ See Rojas and Vilcapoma, 1996.
FIGURE 2

Peru: Trade balance and variation

in international reserves, 1950-1998 a

(As a percentage of exports of goods)

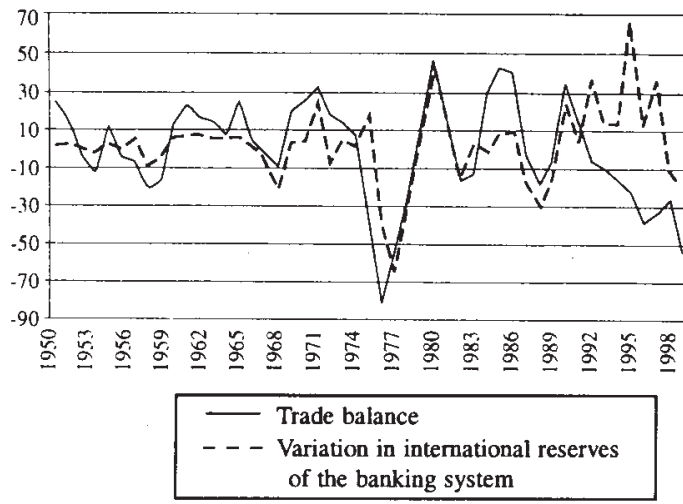

Source: Banco Central

${ }^{\mathrm{a}}$ Up to September 1998.

eign exchange reserves of the banking system (both measured as a percentage of exports) have almost always moved in the same direction over the 45 years in question. ${ }^{15}$ The period from 1991 to 1997 represents the only lengthy exception to this rule. The magnitude of the inflow of capital was particularly marked in the first half of the 1990s, thus making possible a notable increase in the foreign exchange reserves, in spite of a growing trade deficit and greater external debt service commitments.

How did investment behave in each of these three main stages? Figure 3 shows total gross investment as a percentage of GDP between 1950 and 1997. If we simplify the division into periods made by Seminario and Boullon (1992), we can identify five main cycles in the course of those 45 years. A first investment cycle (in mining and export agriculture) occurred in 1950-1960 in connection with the structural reforms made by Odría.

The second investment cycle, which covered the period from 1960 to the early 1970s, was marked by a clear decline in the rate of capital accumulation, probably due to the uncertainty caused by the political crisis of the oligarchic State. ${ }^{16}$

\footnotetext{
15 This suggests that it was the real sector of the economy which governed the rate at which the banking system accumulated external assets.

${ }^{16}$ See Cotler, 1994.
} 
FIGURE 3

Peru: Gross fixed capital formation, 1950-1997

(As a percentage of GDP)

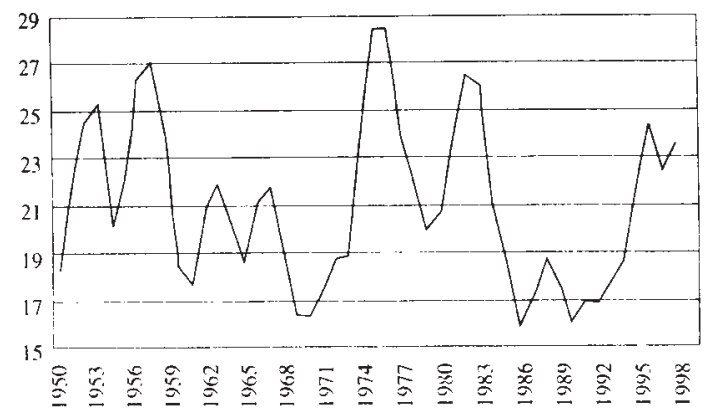

Source: Banco Central de Reserva del Perú.

The third investment cycle, which began with the Velasco Alvarado government and ended with the onset of the external debt crisis in 1982, was marked by the basic role played in it by public investment financed with external indebtedness. This process of State accumulation was interrupted in 1976-1977 by an early external debt crisis associated with the end of the "golden age" of the world economy; ${ }^{17}$ the solution of this crisis through a marked increase in exports ${ }^{18}$ made possible a recovery in public investment at the beginning of the second term of Belaúnde. The 1982-1983 balance of payments problems, connected with another external shock, finally put an end to this cycle.

The fourth cycle (1983-1993) was accompanied by the total collapse of the rate of investment. The burden of the external debt on the fiscal accounts, the growing macroeconomic instability, and the hyperinflation unleashed by the economic policy of the García administration (1985-1990), after the abortive attempt to nationalize the banking system, were the main causes of this decline in investment. It must be emphasized, however, that the internal armed hostilities which began in 1980 also seem to have been a basic factor which gradually destroyed the confidence of the private sector and increased the noneconomic uncertainty, or political risk, to extreme levels. This led to a persistent contraction in private investment, while the expatriation of capital increased. ${ }^{19}$

The fifth and final investment cycle began in 1993, supported by a massive inflow of capital in connection with the privatization of public enterprises and the repatriation of domestic capital. One hypothesis holds that the capture of Abimael Guzmán, the leader of Sendero Luminoso, was the event that permitted the initiation of this cycle by sharply reducing the political risk. An alternative hypothesis, however, attributes this new investment to the stabilization and structural reform programme carried out by the Fujimori administration.

\section{III}

\section{Interpretations of the Peruvian growth process}

There are three basic interpretations of this evolution of the Peruvian economy between 1950 and 1995 . The first of them attributes this performance, whether good or bad, to the growth strategy applied in each period. For example, those who note that much of the

\footnotetext{
17 See Maddison, 1991.

${ }^{18}$ In the late 1970s, two big investment projects, in the areas of copper and petroleum, which had been initiated early in the Velasco Alvarado government, came on stream, there was a rise in the terms of trade, and there was a boom in non-traditional exports.
}

good macroeconomic performance in the first stage took place under a primary-export model, or that almost the whole of the disastrous macroeconomic performance in the second stage took place under an import substitution model with heavy State intervention, are tempted to convert this association into a relation of causality, assuming that the development model, that is to say, the structural reforms in one or

\footnotetext{
${ }^{19}$ See Figueroa, 1993.
} 
the other direction, explain the long-term macroeconomic performance. $^{20}$

The second interpretation attributes this past behaviour of the Peruvian economy to the recurrent fluctuations in the international economy, which have been particularly pronounced since the mid-1970s. ${ }^{21}$ Thus, those who note that the good macroeconomic performance in the first stage coincides almost exactly with the extremely favourable external context created by the "golden age" of Western capitalism described by Maddison (1992) could equally well conclude that it was this international economic situation which explains this performance..$^{22}$

From this point of view, it could also be argued that the stagnation and high inflation of the 1980s were the result of another adverse external shock, similar to that which marked the end of the "golden age" and set off the external debt crisis. Or it could also be asserted that the inflow of capital in the first half of the 1990s, associated with historically low external interest rates, ${ }^{23}$ was decisive for the initiation of the new period of price stability and expansion of the aggregate product which marked the first half of the 1990s throughout Latin America.

The third interpretation of this past experience assigns a leading role to macroeconomic policy, ${ }^{24}$ holding that success or failure depend on the macroeconomic policies adopted during the period. As Marfán and Bosworth (1994) assert in their evaluation of the Chilean experience, whose success normally tends to be associated with structural reforms, what stands out -particularly when appraising the economic events of the last ten years- is the clear benefit of conventional macroeconomic policies emphasizing stable prices and stable growth of demand.

A classic example is the role played by macroeconomic policy in Europe during the "golden age".

\footnotetext{
20 From a pro-industrialization perspective, Schydlowsky and Wicht (1979) and Jiménez (1991) emphasize the intrinsic limitations on a form of industrialization depending on imported inputs and capital goods and aimed exclusively at the domestic market. Paredes and Sachs (1990) and Hunt (1996), in contrast, take an anti-industrialization approach.

21 See Krugman (1988).

22 Iguíñiz (1986), Frenkel, Fanelli and Rosenwurcel (1993) and Taylor (1991) have stressed the importance of the external context as the determining factor of macroeconomic performance. Hofman (1993) shows that per capita GDP growth under the import substitution industrialization model was high in Latin America during the "golden age".
}

According to Maddison (1991), the main achievement of government policy was not "fine-tuning" but the success in feeding a demand boom which kept the economies in a situation of high employment. The pro-growth and pro-employment bias, and the absence of deflationary policies with their crudely perverse effects, were the features which most differentiated post-war domestic policy from pre-war policy. The achievements were greater than could reasonably have been expected. The absence of risks of recession in terms of production and the persistence of satisfactory profits gave rise to an unprecedented investment boom.

Particular emphasis should be placed on the importance of the macroeconomic policies adopted as a reaction to the recurrent external shocks suffered by an economy like that of Peru. It is this interaction between macroeconomic policy and external shocks which gives rise to either balance of payments crises or successful adjustments: particular events which often determine the subsequent performance of the economy in terms of growth and inflation.

As noted by Krugman (1988), a country which suffers severe external shocks can consider itself lucky if it only has to put up with a temporary recession and a spell of inflation rather than a persistent decline in its growth expectations and a permanent shift towards higher rates of inflation. He adds that the macroeconomic policy response is the key to successfully facing up to an adverse external shock.

Thus, for example, an observer who notes that the turning-point in the macroeconomic performance of Peru (the year 1975) coincides not only with an external shock but also with a significant change in the macroeconomic policy applied ${ }^{25}$ might be tempted to extend the conclusions of Marfán and Bosworth to the case of Peru. It might therefore be

\footnotetext{
23 See Calvo, Leiderman and Reinhart (1993).

24 See Thorp (1995), who emphasizes the role of macroeconomic management.

${ }^{25}$ In the mid-1970s, the system of a fixed exchange rate was replaced with a movable rate with a target real exchange rate, and public prices were made a key instrument in fiscal policy. See Thorp (1995) and Fitzgerald (1985).
} 
argued that the inflation and stagnation marking the second stage (from 1975 to 1990) are explained by the interaction of adverse external shocks and this change in macroeconomic policy. ${ }^{26}$
To sum up, then, a prudent conclusion would be that the long-term macroeconomic results do not only depend on the growth strategy followed, but also the international context and macroeconomic policy.

\section{IV}

\section{Economic fluctuations and external shocks}

Both historical $^{27}$ and econometric ${ }^{28}$ studies suggest that an essential component in the form of macroeconomic regulation prevailing during the period from 1950 to 1990 was the particular blend of fiscal, credit and exchange-rate policies applied in response to an adverse or destabilizing external shock (such as a fall in the terms of trade or a rise in international interest rates). This policy mix normally included a devaluation, credit restrictions and a contractionary fiscal policy.

This way of handling adverse external shocks, together with certain structural features of the Peruvian economy, has given rise to set of empirical regularities or stylized events in the short-term dynamics of the economy. These facts are connected with the relations that exist between the short-term cycle of the level of economic activity, the rate of inflation, and the evolution of the external sector (exchange rate, trade balance and foreign currency reserves).

The main point is that the periods of recession are at the same time periods of rising inflation ${ }^{29}$ and of balance of payments crises. It is worth emphasizing that the basic features of these short-

\footnotetext{
${ }^{26}$ In order to close the external and fiscal gaps generated by the increase in the external debt burden, the instruments used were the exchange rate and public prices. First of all their real values rose sharply, and subsequently their nominal values were indexed to past inflation.

${ }^{27}$ For a detailed analysis of all the Peruvian stabilization attempts since the 1950s, see Thorp (1996).

${ }^{28}$ See Seminario and Boullon (1992), Robles (1996), Terrones and Calderón (1993) and Vilcapoma (1996).

${ }^{29}$ A noteworthy empirical regularity of the Peruvian economy is that the rises in inflation coincide with recessions. Three recent studies on the Peruvian experience -Seminario and Boullon (1992), Terrones and Calderón (1993) and Robles (1996), which use different methods for separating the cycle from the trend levels- find that inflation is anticyclical with respect to the level of economic activity.
}

term dynamics, especially the balance of payments crisis-rising inflation-recession chain, are common to the three stages in which we divided these 45 years.

This chain has various links. The first link connects devaluations ${ }^{30}$ with an appreciable decline in the foreign exchange reserves of the banking system. The regularity of this fact reflects a policy rule which prevailed during these 45 years because of the unvarying reaction of the monetary authorities, since the exchange rate has always been managed, one way or another, by the Central Bank.

The second link arises from the observation that the beginning of all the major recessions during these 45 years (namely, in 1953,1957,1967, 1975, 1982 and 1987) coincided with or was preceded by a drop in the reserves due to a deficit on the trade balance; ${ }^{31}$ none of the declines in the international reserves were due exclusively to outflows of capital. Of the six recessions mentioned above, the first five coincide with adverse external shocks. ${ }^{32}$ Two of them (those in 1975 and 1982) were associated with external public debt crises (lower disbursements and rises in international interest rates). ${ }^{33}$

\footnotetext{
30 That is to say, devaluations during the period $1950-1975$, or increases in the rate of devaluation during the period 1976-1995. ${ }^{31}$ See Vilcapoma (1996). The trade balance may deteriorate due to external shocks and/or domestic factors. What we wish to emphasize is that if the trade deficit -whatever its origin- means that the foreign exchange reserves go down, this marks the beginning of a recessionary cycle. During the 1990s, thanks to the inflow of capital, it has been possible for a growing trade deficit to exist at the same time as reactivation of the level of economic activity and an increase in the foreign exchange reserves.

${ }^{32}$ See Dancourt, Mendoza and Vilcapoma (1997).

${ }^{33}$ See Ugarteche (1996) and Cline (1981).
} 
TABLE 1

Correlation between growth rates of GDP

and of other macroeconomic variables, 1950-1996

\begin{tabular}{|c|c|c|c|c|c|c|c|c|}
\hline \multirow{3}{*}{ Growth rate } & \multirow{3}{*}{$\begin{array}{c}\text { Relative } \\
\text { standard } \\
\text { deviation }^{\mathrm{a}}\end{array}$} & \multirow{3}{*}{$\begin{array}{l}\text { Standard } \\
\text { deviation }\end{array}$} & \multirow{3}{*}{$\begin{array}{c}\text { Auto- } \\
\text { correlations }\end{array}$} & \multicolumn{5}{|c|}{ Coefficients of correlation } \\
\hline & & & & \multicolumn{2}{|c|}{ Lags } & \multirow[b]{2}{*}{0} & \multicolumn{2}{|c|}{ Advances } \\
\hline & & & & -2 & -1 & & 1 & 2 \\
\hline$G^{b}$ & 3.0 & 15.7 & $0.44 *$ & 0.08 & $0.48 * *$ & $0.62 * *$ & $0.45^{* *}$ & 0.11 \\
\hline $\mathrm{T}^{\mathrm{c}}$ & 2.7 & 13.8 & $0.33 *$ & -0.30 & 0.11 & $0.64 * *$ & $0.50 * *$ & $0.42 * *$ \\
\hline$L^{d}$ & 4.0 & 20.9 & $0.41 * *$ & -0.24 & 0.15 & $0.58 * *$ & 0.30 & 0.23 \\
\hline $\mathrm{P}^{\mathrm{e}}$ & 234.1 & 1217.1 & 0.36 & -0.28 & $0.53 * *$ & $-0.44 * *$ & -0.20 & -0.21 \\
\hline$E^{f}$ & 139.1 & 723.2 & 0.15 & -0.20 & $-0.35 *$ & $-0.47 * *$ & $-0.34^{*}$ & -0.27 \\
\hline $\mathrm{E} / \mathrm{P}^{\mathrm{g}}$ & 4.2 & 21.7 & $-0.42 *$ & 0.12 & $0.42 * *$ & -0.03 & $-0.32 *$ & 0.05 \\
\hline$X^{h}$ & 1.8 & 9.6 & 0.00 & -0.01 & 0.01 & 0.23 & 0.12 & $0.46^{* *}$ \\
\hline$M^{i}$ & 3.0 & 15.7 & 0.27 & -0.18 & $0.41 * *$ & $0.65^{* *}$ & 0.12 & -0.21 \\
\hline $\mathrm{CM}^{\mathrm{j}}$ & 6.0 & 31.2 & $-0.30 *$ & $-0.31 *$ & 0.09 & $0.43^{* *}$ & 0.00 & 0.08 \\
\hline \multicolumn{9}{|l|}{ Levels } \\
\hline $\mathrm{T}-\mathrm{G}^{\mathrm{k}}$ & & & 0.24 & $-0.35^{*}$ & -0.05 & 0.24 & $0.36^{*}$ & 0.38 \\
\hline $\mathrm{X}-\mathrm{M}^{\mathrm{l}}$ & & & $0.56^{*}$ & -0.23 & $-0.53 * *$ & $-0.30 *$ & 0.15 & 0.24 \\
\hline A-RIN ${ }^{\mathrm{m}}$ & & & $0.32 *$ & $-0.14 * *$ & -0.19 & 0.14 & 0.19 & $0.44 * *$ \\
\hline
\end{tabular}

Source: Dancourt, Mendoza and Vilcapoma (1997).

* Significant at $95 \%$.

** Significant at $99 \%$.

${ }^{\text {a }}$ Ratio of standard deviation of variable to that of GDP.

${ }^{\mathrm{b}}$ Real expenditure of central government.

${ }^{c}$ Real tax revenue of central government.

d Total real credit of banking system to private sector.

e Consumer Price Index.

${ }^{\mathrm{f}}$ Nominal exchange rate at end of period.

${ }^{\mathrm{g}}$ Real exchange rate at end of period.

h Real exports.

${ }^{\mathrm{i}}$ Real imports.

${ }^{\mathrm{j}}$ Index of import capacity.

${ }^{\mathrm{k}}$ Saving on current account without capital inflows.

${ }^{1}$ Trade balance.

${ }^{\mathrm{m}}$ Flow of international reserves of the banking system.

The third link in the chain is the observation that during these 45 years there was practically no important episode of rising inflation which was not associated with a devaluation or an increase in the rate of devaluation.

To sum up this short-term dynamic, we can say that during the period when there was a fixed nominal exchange rate (1950-1975), the recessions were associated with declines in the reserves and individual devaluation measures which caused a transitory rise in the rate of inflation. Once the balance of payments crisis was over, inflation slackened once again. ${ }^{34}$

There are various factors which would appear to have governed this short-term dynamic. The first is that unvarying policy rule which causes the authorities to devalue the exchange rate only when the for-

${ }^{34}$ In contrast, when an attempt was made to fix the real exchange rate and real public prices (roughly speaking, in the period 1976-1990) inflation did not slacken as soon as the balance of payments crisis was over. eign exchange reserves go down. The second is that a rise in the real exchange rate may be recessionary and inflationary in the short term, in line with the TaylorKrugman model (see Krugman and Taylor, 1978). The third is that a rise in the real exchange rate has normally formed part of a package of measures for dealing with a balance of payments crisis; such a package generally includes restrictive fiscal and credit policies. ${ }^{35}$

Table 1 shows the correlations between the growth rates of aggregate GDP, with different lags and advances, and the growth rates of a set of macroeconomic variables (prices, the exchange rate, public expenditure, credit, the trade balance, etc.). This table makes it possible to classify the various macroeconomic variables as procyclical or anticyclical with respect to GDP, ac-

\footnotetext{
35 The studies by Seminario and Boullon (1992), Robles (1996), Terrones and Calderón (1993) and Vilcapoma (1996) find that the real exchange rate is anticyclical, that real wages are procyclical, and that credit for the private sector is procyclical and much more volatile than GDP. Vilcapoma (1996) also shows that some components of public expenditure are procyclical.
} 
cording to whether the coefficient of correlation is positive or negative. As it would not be appropriate to try to represent the structure of lags and advances of the different macroeconomic variables with respect to GDP on the basis of annual data, we shall refer only to the current correlations.

These coefficients of correlation between the GDP growth rates and the various macroeconomic variables cover the whole period 1950-1996, without drawing any distinction between phases of boom or recession, and they sum up in a single number the type and degree of association of the fluctuations in the level of activity with those variables.

In general terms, table 1 confirms the main stylized facts described earlier. A first result is that inflation and devaluation are clearly anticyclical (they rise in times of recession and go down in boom periods). A second result is that public expenditure and real credit are highly procyclical (they go up in boom periods and go down in recessions). A third result is that imports and import capacity are clearly procyclical, whereas the trade balance is anticycli$\mathrm{cal}^{36}$ (it deteriorates in boom periods and improves in recessions). Finally, we see that taxes are procyclical and that the primary central government fiscal surplus is acyclical. ${ }^{37}$

Among the anomalous results (anomalous with respect to the pattern of booms and recessions we described) is, firstly, the fact that the real exchange rate is acyclical in current terms. ${ }^{38}$ Secondly, there is the fact that the variations in the foreign exchange reserves of the banking system are acyclical in current terms. This may be because booms do not display such a systematic or regular pattern as recessions.

\section{V}

\section{Stabilization and dollarization}

Although it is possible today to apply a faithful replica of the growth strategy of 40 years ago, it is not possible to do the same in the field of macroeconomic policy. The basic idea in this section is that the policy mix used in the first stage (from 1950 to 1975) to deal successfully with adverse external shocks cannot be applied in the 1990s.

As we shall see, the financial liberalization measures of the 1990s have blocked the mechanisms traditionally used in the Peruvian economy to deal with external shocks, by notably reducing the power of monetary policy: today, the Central Bank is no longer capable of imposing credit restrictions, nor is it easy for it to devalue the currency.

Two main macroeconomic policy systems may be identified during the Fujimori administration. In the first period (1990-1992), the macroeconomic policy mix used consisted of a monetary target (the Central Bank regulated the amount of domestic money in circulation by buying or selling dollars) and active fixing of public prices, which was the key fiscal policy instrument.

In this system, there was a clear division of labour between monetary policy and fiscal policy. Monetary policy was indirectly responsible for controlling inflation, by fixing decreasing rates of growth of the amount of money in circulation. Fiscal policy, for its part, generated a primary surplus designed to cover payments on the external debt by raising the real prices of fuels for the public. ${ }^{39}$

The restrictive monetary policy caused exchangerate appreciation which, in turn, checked the rise in price levels, but the increase in public prices acted in the opposite direction. These dual effects explain why the disinflation in 1990-1992 was slow and displayed pronounced setbacks associated with marked fluctuations in the rate of devaluation and frequent shocks caused by public prices. Even so, this experi-

\footnotetext{
${ }^{36}$ The anticyclical nature of the trade balance is observed with a certain amount of lag (first the GDP rises and then the trade balance deteriorates, and vice versa).

${ }^{37}$ We were expecting it to be procyclical, i.e., that it would have a destabilizing effect. See Gavin, Hausmann, Perotti and Talvi (1997).

${ }^{38}$ We believe this is connected in part with the definition of the real exchange rate used, which does not incorporate international inflation. It is clear, however, that all the recessions that took place between 1950 and 1996 began with a rise in the real exchange rate.

${ }^{39}$ There was an intermediate period, in the second half of 1990 , in which the anti-inflationary policy consisted of fixing the nominal exchange rate and public prices, after the style of the heterodox plans of the 1980s, the Bolivian experience of 1985, or the Argentine experience with Cavallo. See Dancourt, 1996.
} 
TABLE 2

Peru: Macroeconomic indicators, 1991-1997

(Annual variation)

\begin{tabular}{|c|c|c|c|c|c|c|c|}
\hline & 1991 & 1992 & 1993 & 1994 & 1995 & 1996 & 1997 \\
\hline Non-primary sector ${ }^{a}$ & 3.6 & -1.7 & 6.2 & 14.1 & 9.5 & 1.7 & 9.7 \\
\hline Primary sector ${ }^{b}$ & 1.85 & -5.1 & 8.0 & 11.6 & 2.3 & 4.6 & 4.7 \\
\hline GDP & 2.9 & -2.8 & 6.5 & 13.1 & 7.0 & 2.6 & 7.4 \\
\hline Domestic demand less imports & 2.0 & -3.1 & 7.5 & 11.7 & 7.0 & -0.3 & 4.6 \\
\hline Public investment & 6.4 & 13.9 & 12.8 & 21.9 & 14.5 & -8.5 & 9.0 \\
\hline Exports & 6.0 & 2.5 & 3.3 & 17.5 & 7.0 & 11.4 & 16.3 \\
\hline Trade deficit ${ }^{\mathrm{c}}$ & -8.3 & -9.7 & -17.0 & -21.3 & -38.8 & -33.9 & -30.5 \\
\hline Index of GDP $(1987=100)$ & 79.8 & 78.4 & 83.3 & 94.3 & 100.8 & 103.0 & 111.2 \\
\hline Inflation & 139.2 & 56.7 & 39.5 & 15.4 & 10.2 & 11.8 & 6.5 \\
\hline Devaluation & 85.9 & 69.8 & 31.9 & 1.4 & 6.5 & 12.1 & 4.7 \\
\hline Price of fuels & 114.1 & 42.5 & 41.7 & 4.4 & 6.3 & 32.2 & 23.4 \\
\hline Total credit to private sector & 284.8 & 96.4 & 74.0 & 65.0 & 43.6 & 49.6 & 30.1 \\
\hline
\end{tabular}

Source: Banco Central de Reserva del Perú (1995 and 1998).

${ }^{a}$ Comprises non-primary commodity-based industry, construction, government, commerce, etc.

${ }^{\mathrm{b}}$ Comprises agriculture, fisheries, mining and primary commodity-based manufacturing.

${ }^{\mathrm{c}}$ As a percentage of exports.

FIGURE 4

Peru: Service paid on the public debt, 1987-1997 (As a percentage of exports of goods)

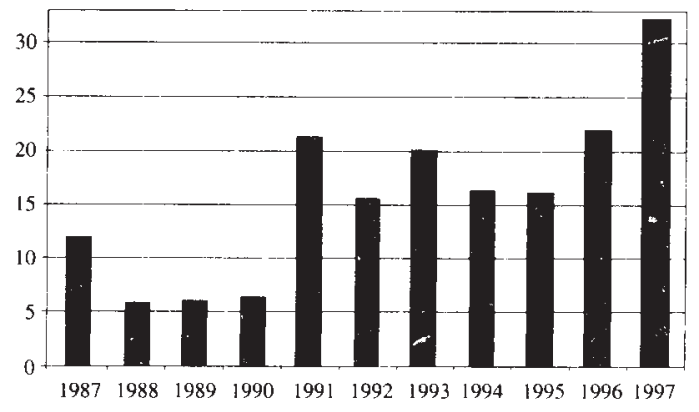

Source: Banco Central de Reserva del Perú (various issues).

ence serves to confirm once more the effectiveness of overvaluation of the exchange-rate as a means of controlling inflation, in the case of Peru.

The process of controlling hyperinflation in Peru has been notably slow compared with similar processes in economies that were also dollarized, such as those of Bolivia (1985) or Argentina (1991). From the beginning of the stabilization programme until the point at which a rate of inflation (in terms of the consumer price index) of less than $2 \%$ per month was registered for three consecutive months, the Peruvian stabilization process took 37 months (from August 1990 to September 1993), the Argentine process took four months (from April to August 1991) and that of
Bolivia took 13 months (from August 1985 to September 1986).

Such a policy mix did serve, however, to reconcile the disinflation process with the increase in the external debt service, which it had not been possible to do in the 1980s. The two immediate objectives of the economic programme of the Fujimori administration were to end hyperinflation and normalize the country's relations with the international financial community. This latter objective meant resuming the servicing of the external public debt (figure 4), first to the multilateral agencies, then to the member governments of the Paris Club, and finally to the international commercial banking system within the context of the Brady Plan.

The period of application of this policy mix, as may be seen from table 2, was marked by slow disinflation, stagnation of the level of economic activity at its lowest level, and enormous over-valuation of the real exchange rate.

The mechanism behind this appreciation of the real exchange rate may be summed up as follows. On the one hand, through the purchase of dollars, monetary policy fixes a certain rate of increase of the domestic money supply. On the other hand, fiscal policy pushes the rate of inflation above the growth of the money supply through periodic readjustments in public prices, thus reducing the real amount of money.

In view of the level of activity, this means that the public lacks national currency (means of ex- 
change) for carrying out its transactions. In order to obtain this money, the public can immediately sell dollars (the value reserve par excellence in a dollarized economy like that of Peru) or, in the mediumterm, change its habits as regards the use of money, becoming accustomed to carry out more and more transactions directly in dollars..$^{40}$

The hypothesis put forward in this article is that it was the first of these reactions which was the main force behind the exchange rate over-valuation. As may be seen from figure 5, most of the exchange lag which marks the Fujimori administration took place at the beginning of the stabilization programme; in August 1990 the general price level rose by a factor of five because the government raised fuel prices by a factor of 30, the real monetary base shrank by twothirds, and the real free exchange rate sank to half the level of the previous month.

Subsequently, in addition to these factors there was the more gradual impact of the inflow of foreign capital, which put downward pressure on the exchange rate, altering the relative supply of soles and dollars. ${ }^{41}$

Under the second macroeconomic policy system (1993-1995), the policy mix was changed. In order to explain the change from the previous system to this one, it must be borne in mind firstly that public income from privatization operations became a significant factor as from 1993-1994 and, secondly, that Fujimori was seeking re-election in the 1995 elections.

The real price of fuels gradually went down, and public expenditure came to be the preferred fiscal policy instrument. The monetary targets were replaced with exchange-rate targets which appreciably reduced the permissible range of fluctuation of the exchange rate until it came close to a fixed exchange rate. One indicator of this transition is the relative volatility ${ }^{42}$ of the exchange rate with respect to the amount of money in circulation, which went down from 2.34 in 1991-1992 to 0.21 in 1993-1995.

\footnotetext{
40 They can, of course, also seek more bank credit or sell off their stocks of goods. The first of these actions does not represent a serious objection for the argument put forward here, while the second has not been observed in the Peruvian economy.

${ }^{41}$ Ruiz (1995) compares the two hypotheses econometrically (monetary policy versus inflow of capital) and reaches a conclusion in line with the view that the exchange rate appreciation was generated directly by the monetary policy.

42 That is to say, the standard deviation of the monthly devaluation, divided by the standard deviation of the monthly growth of the monetary base.
}

FIGURE 5

Peru: Real exchange rate, January 1989-July 1998 (August 1990=100)

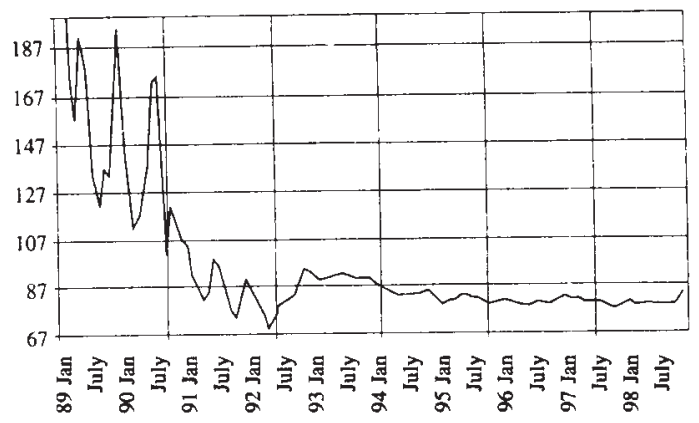

Source: Banco Central de Reserva del Perú (various issues).

As may be seen from table 2, the period in which this second policy mix was applied was marked by a rapid decline in inflation -associated with the virtual fixing of the exchange rate and of nominal public prices-, a notable reactivation of economic activity, connected with the expansionary fiscal policy, and a much smaller degree of appreciation of the real exchange rate. This marked the close of the inflationary cycle which had begun in the mid-1970s.

In both periods, the inflow of capital made it possible for the foreign exchange reserves to increase in spite of the growing trade deficit, thus providing a way out from the conflict between price stability and external equilibrium which has marked the Peruvian economy over these 45 years. (If the exchange rate is used to check price rises, the trade balance deteriorates, and vice versa). Clearly, this exchange rate overvaluation -and its anti-inflationary impact- could not have lasted without the inflow of foreign capital.

It might be concluded from this brief description that the macroeconomic policies applied and the rate of inflation in the period from 1993 to 1997 came quite close to the system of a fixed exchange rate and $10 \%$ annual inflation observed at the height of the primary-export model.

This similarity is more apparent than real, however. As already noted, the credit and exchange policy mix which was used in the 1950s and 1960s to cope with external shocks cannot be used in the 1990s, basically because two structural reforms associated with financial liberalization -the dollarization of the banking system and the opening up of the capital accountprevent monetary policy from operating properly. 
TABLE 3

Peru: Monetary indicators, $1990-1997^{a}$

\begin{tabular}{|c|c|c|c|c|c|c|c|c|c|c|c|}
\hline \multirow{4}{*}{ Year } & \multirow{4}{*}{$\begin{array}{c}\text { Monetary } \\
\text { base } \\
(1989= \\
100)\end{array}$} & \multicolumn{9}{|c|}{ Commercial banks } & \multirow{4}{*}{$\begin{array}{c}\text { Interna- } \\
\text { tional } \\
\text { reserves } \\
\text { of the } \\
\text { banking } \\
\text { system } \\
\text { (Millions } \\
\text { of } \\
\text { dollars) }\end{array}$} \\
\hline & & \multirow{2}{*}{\multicolumn{2}{|c|}{$\begin{array}{l}\text { Foreign currency } \\
\text { deposits }\end{array}$}} & \multicolumn{2}{|c|}{$\begin{array}{l}\text { Foreign currency } \\
\text { loans }\end{array}$} & \multirow{3}{*}{$\begin{array}{c}\text { Interna- } \\
\text { tional } \\
\text { liabilities } \\
\text { (\% of } \\
\text { foreign } \\
\text { currency } \\
\text { loans) }\end{array}$} & \multicolumn{4}{|c|}{ Real annual interest rates } & \\
\hline & & & & & & & \multicolumn{2}{|c|}{ Foreign currency } & \multicolumn{2}{|c|}{ Local currency } & \\
\hline & & $\begin{array}{l}\text { of } \\
\text { US\$ }\end{array}$ & $\begin{array}{c}\text { total } \\
\text { deposits }\end{array}$ & $\begin{array}{l}\text { of } \\
\text { US\$ }\end{array}$ & $\begin{array}{l}\text { total } \\
\text { loans }\end{array}$ & & Loans & Deposits & Loans & Deposits & \\
\hline 1990 & 69 & 0.756 & 63 & 0.451 & 64 & 15 & $\ldots$ & $\ldots$ & $\ldots$ & $\ldots$ & 531 \\
\hline 1991 & 56 & 2.163 & 75 & 1.242 & 68 & 7 & -10.0 & -19.4 & 43.9 & -29.6 & 1304 \\
\hline 1992 & 58 & 2.627 & 75 & 1.755 & 76 & 13 & 26.3 & 13.7 & 72.0 & -24.2 & 2174 \\
\hline 1993 & 56 & 3.875 & 82 & 2.732 & 79 & 14 & 9.0 & -0.07 & 23.6 & -18.2 & 2793 \\
\hline 1994 & 72 & 5.280 & 77 & 3.308 & 74 & 15 & 1.0 & -8.0 & 20.5 & -7.0 & 4737 \\
\hline 1995 & 89 & 6.090 & 74 & 5.426 & 71 & 19 & 13.2 & 2.5 & 21.1 & -0.3 & 6693 \\
\hline 1996 & 79 & 8.007 & 75 & 7.268 & 74 & 23 & 17.1 & 6.0 & 16.8 & -1.2 & 8862 \\
\hline 1997 & 85 & 8.976 & 73 & 8.537 & 77 & 28 & 13.7 & 3.5 & 22.5 & 3.2 & 7963 \\
\hline
\end{tabular}

Source: Banco Central de Reserva del Perú (various issues).

${ }^{\mathrm{a}}$ Data at end of each period.

In order to understand this result, it is worth describing the institutional framework in which monetary policy operates. In the Peruvian financial system there is no market for debt paper or public bonds, and the stock exchange has little macroeconomic importance. Instead, it is the banking system and an extensive and well-organized market for exchanging dollars which are the two central institutions in the financial system.

These two basic institutions have been combined in various ways from 1980 to the present. During the Belaúnde administration (1980-1985), the banking system accepted deposits and granted loans in both national currency and foreign currency, a system of mini-devaluations was applied, and the free exchange rate closely followed the official rate.

In the first years of the García administration (1985-1987) the banking system was de-dollarized, a system of multiple fixed exchange rates was applied, and there was a stable differential between the free exchange rate and the highest official exchange rate. Subsequently, between 1988 and 1990, hyperinflation led to the dollarization of the private sector's financial holdings, but now outside the banking system; the official exchange rate gradually lost all significance, and the foreign exchange market expanded considerably, with the dollar consolidating its position as the main reserve asset of the Peruvian economy.

Finally, with the Fujimori administration, the development banking system was closed down, the pri- vate commercial banks were once again authorized to accept deposits and grant loans in foreign currency, and a flexible exchange-rate system was introduced. At the present time, three-quarters of all loans and deposits are dollarized, and the exchange-rate system, as already mentioned, is increasingly close to a fixed exchange-rate system, although without any explicit commitment on the part of the monetary authority. ${ }^{43}$

This latter dollarization of the banking system is the combined result of this authorization and the exchange-rate float. With this float, the Central Bank gained the capacity to control the amount of domestic money in circulation. This control also prevented the private sector from automatically remonetizing itself by ceasing to hoard the foreign currency accumulated during the period of hyperinflation once that period was over, as usually occurs with a fixed exchangerate system.

Consequently, the dollar bills went to the banks instead of being changed into soles. Introducing the dollar into the banking system meant associating the foreign currency with the saving of transaction costs characteristic of a system of bank payments, as well as converting it into an interest-bearing asset.

There was thus a massive increase in deposits in dollars, as may be seen from table 3 . This increase

\footnotetext{
${ }^{43}$ Exchange-rate floating still occupies a leading place in the official discourse of the Peruvian economic authorities.
} 
came from three sources. First, there was the entry into the domestic banking system of the dollar bills saved up during the period of hyperinflation. Second, there was the repatriation of capital and the inflow of short-term capital by non-residents. Third, there were the loans obtained abroad by the local commercial banking system as from late 1994. It should be noted that the inflow of foreign exchange generated by the privatization of public enterprises (whose counterpart mainly takes the form of foreign direct investment) does not represent a fourth source, since this money remained outside the country and outside the domestic banking system; ${ }^{44}$ it would only represent such a source if the government financed its expenditure by selling these dollars to the public.

The consequences of this process of dollarization of deposits for the relations of the commercial banking system with its debtors and with the Central Bank have been very far-reaching.

First, the increase in deposits in dollars made possible a significant expansion in bank credit to the private sector. Second, apparently because of the desire of the banks to tie their assets and liabilities by currencies in order to avoid exchange risk, this expansion in credit has led to the dollarization of the indebtedness of non-financial enterprises (table 3 ).

Third, the increase in bank deposits in foreign currency has also represented a considerable increase in the net international reserves of the Central Bank, through the high compulsory reserve rate applicable to these deposits; at the end of 1996, these compulsory reserves represented $40 \%$ of the total foreign exchange reserves of the monetary authority. This arrangement can also have the opposite effect, however, since a run on bank deposits in dollars is automatically also a run on the Central Bank reserves.

Fourth, this process has radically altered the terms in which the Central Bank must fulfill its role of lender of last resort in the event of a run by domestic or foreign depositors; thus, the foreign exchange reserves of the Central Bank now not only fulfill the

\footnotetext{
44 At the end of 1996, these funds represented $37 \%$ of the total foreign exchange reserves of the Central Reserve Bank of Peru. 45 According to Seminario (1995), dollarization has given rise to a monetary system which combines the systems based on free and fixed exchange rates. In reality, the Central Bank issues two currencies. The first of them (bank deposits in dollars) has a fixed parity with the dollar and is $100 \%$ backed by international assets. The second currency is the Peruvian sol, which has a free parity with the dollar.
}

traditional function of providing international liquidity to cushion the impact of the various external shocks to which the Peruvian economy is exposed, but also represent the ultimate guarantee of the stability of the national banking system. ${ }^{45}$

Within this institutional framework, monetary policy operates both through the dollar market and through the banking system. The main monetary policy instruments are now intervention in the exchange market (purchase or sale of dollars to regulate the amount of money or fix the exchange rate), compulsory reserve requirements on bank deposits, the rate of interest or remuneration paid by the Central Bank on the compulsory reserves deposited by the commercial banks, and the financial assets (previously deposits, but now securities issued by the Central Bank itself) which the monetary authority can offer the commercial banks.

In view of this institutional context, the exchange rate and the supply of bank credit are the two main transmission belts linking monetary policy with the level of economic activity, the trade balance and inflation. ${ }^{46}$

However, the dollarization of the banking system and the free movement of capital have markedly reduced the power of monetary policy, by inhibiting these two main channels of transmission. Firstly, the monetary authorities cannot regulate the aggregate supply of credit, whatever the exchange-rate regime in force.

If the Central Bank is willing to allow a clean float of the exchange rate, the monetary authorities could take action (through the purchase or sale of dollars and/or Central Bank paper) to regulate the monetary base and the supply of bank credit in domestic currency: that is to say, only a quarter of the total supply of credit, even in the best of cases. The problem is that, because of the dollarization of the economy, the Central Bank has no way of regulating the volume of credit in dollars, which represents three-quarters of the total supply, without limiting the free movement of capital in some way. ${ }^{47}$

\footnotetext{
46 Seminario (1995) and Dancourt and Mendoza (1996) both present models with these features. Ruiz (1995), using the autoregressive vectors technique, concludes that the main channel for the transmission of changes in money issue appears to be the exchange rate, not interest rates.

47 Of course, if the banking system were de-dollarized, the Central Bank could regulate the aggregate supply of credit by adopting an exchange-rate float, without any need to interfere with the free movement of capital.
} 
Secondly, the dollarization of the banking system also blocks the other channel for the transmission of monetary policy, which operates through the exchange rate. In these circumstances, enterprises and families who receive their income in soles have their indebtedness denominated in dollars. If it is accepted that the Central Bank can bring about an appreciation in the real exchange rate by raising the nominal price of the dollar, then a devaluation means raising real interest rates and the real debt burden.

Because of inflation, the real average cost of credit or the real debt burden depend directly on the interest rates in dollars (which follow the international levels, taking into account compulsory reserve requirements and country risk), the rate of devaluation, the interest rate in soles, and the relative proportions of the credit granted in soles and dollars. The stylized fact is that the real average rate on loans closely follows the rate of devaluation, as shown in figure 6 .

Thus, a midi- or maxi-devaluation can abruptly increase the overdue debt portfolio of the banks, with the risk of bringing on a banking crisis. This effect of a possible maxi-devaluation has considerably strengthened the coalition of interests opposing such a measure, by including among its members both the banks and their debtors. The strength of this coalition, and the fear of further aggravating an external imbalance with a banking crisis, prevent the Central Bank from using the exchange rate as it did in 1950-1975.

In short, the monetary authorities of the 1990s cannot restrict credit, nor can they easily carry out significant devaluations.

In reality, the problem is even more complex, because Peruvian fiscal policy in the 1990s has little flexibility, on account of the size of the external public debt commitments. Let us assume that the net payments in respect of the external debt (debt service less fresh disbursements) are positive, that tax revenue depends on the level of activity, and that the policy rule is that the primary fiscal surplus is equal to the net payments on the external public debt. In these conditions, in which the government does not receive any loans from the domestic banking system, fiscal expenditure ceases to be a policy tool and becomes an adjustment or endogenous variable. In other words, public expenditure will depend directly on the level of economic activity and inversely on the real debt burden, while the latter, for its part, will depend directly both on international interest rates and on the real exchange rate.
FIGURE 6

Peru: Real interest rate on loans and rate of devaluation, January 1993-July 1998

(Annual rates; mobile quarterly averages)

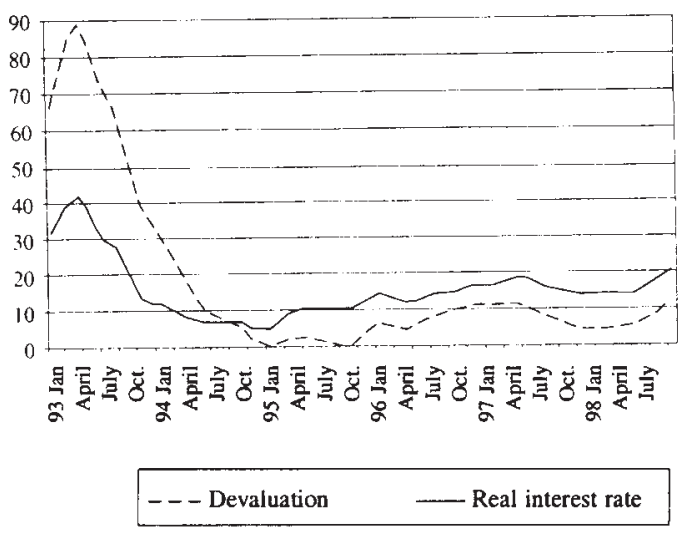

Source: Banco Central de Reserva del Perú (various issues).

In view of the rates of taxation, this fiscal system not only represents a powerful channel for the transmission of external shocks (for example, if international interest rates rise, public expenditure falls) but also functions as an automatic destabilizer. When the level of activity goes down for any reason and tax revenue diminishes, public expenditure also goes down, thus further strengthening the initial recessionary impulse. It is no longer possible to raise public expenditure in order to prevent the onset of a recessionary cycle. Nor is it possible to do this in order to offset the impact of a devaluation (if this is of a recessionary nature, because it causes real wages to go down and/or raises real interest rates) or of a restrictive credit policy.

If public expenditure includes, for example, an unemployment insurance scheme, then the system acts as an automatic stabilizer. Expenditure goes up when the level of activity goes down, and vice versa. This system assumes that the primary fiscal deficit (or surplus) is a freely adjustable variable, i.e., a variable whose value is not fixed exogenously by the debt payment requirements.

Of course in the short term the use of the resources obtained from privatization operations ${ }^{48}$-or greater external indebtedness- could prevent the operation of this automatic destabilizer, leaving open the possibil-

\footnotetext{
48 At the end of 1996, such resources were equivalent to $40 \%$ of annual fiscal income.
} 
ity of increasing public expenditure when the level of activity goes down. However, the future trajectory of the public external debt service commitments suggests that the problem will not easily be solved. ${ }^{49}$

Thus, the feasible set of macroeconomic policy mixes is severely restricted. This is a structural defect of the present macroeconomic policy system, if it is acknowledged that the normal handling of the current economic situation -and not just the management of adverse external shocks- should be the responsibility of monetary policy rather than fiscal policy, because of its greater flexibility and smaller relative power.

\section{VI}

\section{The tequila effect (1995) and the Russian crisis (1998)}

A description of these two macroeconomic situations marked by a financial crisis will make it possible to identify more clearly the nature of the connections that the Peruvian economy currently has with the international financial markets, as well as illustrating how some nerve centres of the prevailing macroeconomic policy system operate and what their limitations are.

In mid-1995, the expansionary cycle that the Peruvian economy had been experiencing since 1993 was abruptly interrupted. The growth rate of the non-primary sector of the economy, ${ }^{50}$ which is the sector that responds to fiscal and monetary policies, fell abruptly to $1.7 \%$ in 1996, after having stood at 9.5\% in 1995 (table 2). In contrast, the primary sector, which comprises agriculture and commodity export activities, and whose level of production is determined basically by supply-side factors, increased its growth rate between 1995 and 1996 from $2.3 \%$ to $4.6 \%$ per year.

The interruption in this growth cycle was not caused by an adverse external shock -the tequila effect- as occurred in Argentina. It is true that in the first quarter of 1995 there were all the symptoms of an outflow of short-term capital, but this phenomenon did not display the virulence observed in other parts of Latin America. Foreign currency deposits went down, there was a fall in the foreign exchange reserves of the banking system, dollar interest rates

\footnotetext{
49 See Ugarteche, 1996.

${ }^{50}$ The non-primary sector comprises manufacturing (other than that based on the processing of primary resources), construction, commerce, etc.
}

rose, the stock exchange slumped, and the Central Bank had to assume its role of lender of last resort to the commercial banking system and intervene in the exchange market.

However, this outflow of short-term capital did not have a great deal of effect on the economy, basically because it did not give rise to an appreciable increase in the real exchange rate or a reduction in the supply of bank credit. As we saw earlier, these are the two transmission belts linking monetary policy and financial crises with the real sector of the economy.

This relative feebleness of the tequila effect may be explained first of all by the nature of the Peruvian financial system. As there is no public securities market and the stock exchange is only small, Lima was not an international financial centre capable of attracting a significant portion of the short-term nonresident capital that went to the Latin American markets in the first half of the 1990s. It was presumably this capital which was sensitive to United States interest rates or to events such as the Mexican crisis in late 1994.

Secondly, most of the short-term capital inflows into the Peruvian economy which took place up to 1994 should probably be classified as repatriation of capital. Such capital is not really volatile short-term capital. The fact is that long-term political considerations -such as the defeat of subversive movementsmay carry a lot of weight in deciding whether or not to repatriate capital.

In other words, a financial system based mainly on the banks and an inflow of capital which was not very sensitive to external interest rates caused the Peruvian economy to be relatively disconnected from 
the United States financial markets, even though the Peruvian neoliberal programme radically opened up the capital account in the early 1990s. This explains why there was no tequila effect in Peru. Unlike Chile, where this was the result of deliberate policy decisions, in Peru this relative disconnection from the international financial markets was merely the result of circumstances. ${ }^{51}$

As may be seen from figure 7, the 1990s has been marked by a big inflow of capital, which was especially marked during the three-year period 19941996. Thus, the cooling down of the economy in 1996 coincided with an enormous inflow of capital equivalent to some $80 \%$ of exports. This inflow of short- and long-term capital only went down appreciably quite recently, in 1997. Likewise, figure 8 shows that the international reserves of the banking system grew rapidly from 1994 to the beginning of 1997 , when they stabilized at around US $\$ 8.5$ billion.

The interruption in the economic reactivation was entirely due to a violent turnaround in fiscal policy which began in mid-1995 and became still more marked in 1996. The origin of this turnaround is to be found in the Letter of Intent which the Government signed with the International Monetary Fund (IMF) in 1995, undertaking to take active measures to cool down the economy.

It may be seen from table 2 that the slump in the growth rate of the Peruvian economy in 1996 was due to the contraction in absolute terms in domestic demand less imports. Of the various components of domestic demand, that which displays the most volatile behaviour is, paradoxically, public investment, which went down by $8.5 \%$ during 1996 after having grown by $15 \%$ the year before. The other indicator of the severity of the budget adjustment is that the public sector primary fiscal surplus significantly increased in spite of the cooling-down of the economy (table 4).

\footnotetext{
51 These circumstances have been changing rapidly since 1995 , however, with the growing short-term external indebtedness of the local commercial banking system. This process, which is described later in this article, strengthens the links between external interest rates and the cost and availability of domestic credit, on the one hand, and the exchange rate, on the other. For an analysis of the different effects of the rise in external interest rates on a dollarized banking system, see Dancourt and Mendoza, 1996.
}

FIGURE 7

Peru: Net inflow of capital

(total and short-term), 1987-1997

(As a percentage of exports of goods)

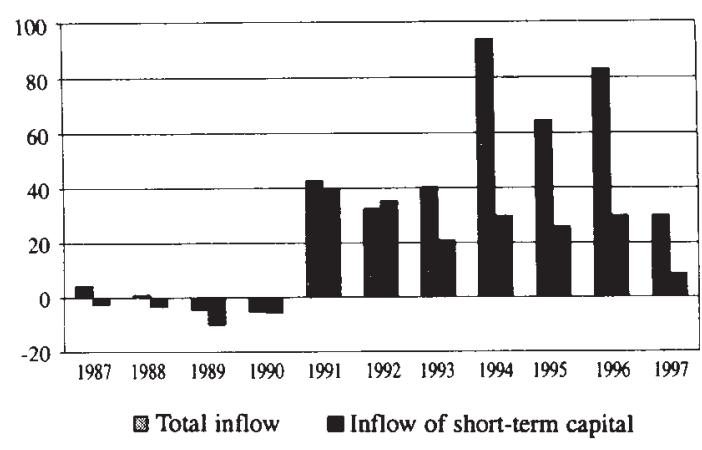

Source: Banco Central de Reserva del Perú (various issues).

FIGURE 8

Peru: Net international reserves of the banking system, January 1994-July 1998 (Millions of dollars)

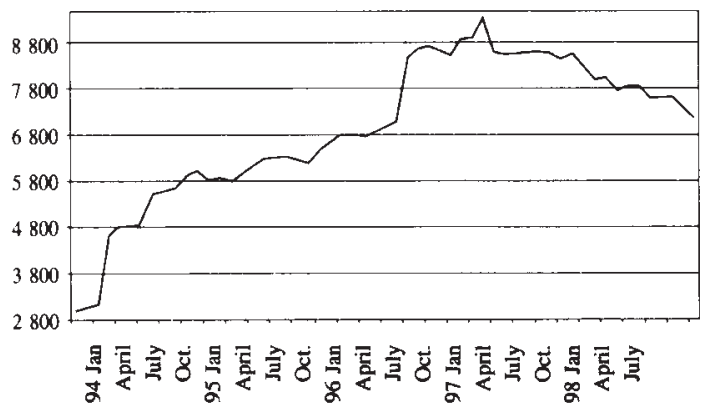

Source: Banco Central de Reserva del Perú (various issues).

There are three factors which can explain this turnaround. Firstly, the Mexican crisis convinced the IMF that a persistent trade deficit could be dangerous if it was financed with capital that could suddenly leave the country, and the policy conclusion was that it was necessary to cool down the economy in order to reduce the trade imbalance. The second factor was connected with the political cycle of public expenditure: after the re-election of Fujimori at the beginning of 1995 there was no longer much government resistance to a cut in such expenditure. Moreover -and this was no less important- the fiscal accounts had to adapt to the increase in external debt service due to the agreements made in 1995-1996 with the creditor 
TABLE 4

Peru: Fiscal indicators of operations of the

non-financial public sector (NFPS), 1991-1998

(As a percentage of GDP)

\begin{tabular}{|c|c|c|c|c|c|c|c|c|c|c|c|}
\hline \multirow{3}{*}{ Year } & \multicolumn{5}{|c|}{ Saving on current account } & \multirow{2}{*}{\multicolumn{2}{|c|}{$\begin{array}{c}\text { Capital } \\
\text { expenditure }\end{array}$}} & \multirow{3}{*}{$\begin{array}{c}\text { Primary } \\
\text { result } \\
\text { of } \\
\text { NFPS }^{\mathrm{a}}\end{array}$} & \multirow{3}{*}{$\begin{array}{c}\text { Capital } \\
\text { income } \\
\text { of } \\
\text { NFPS }\end{array}$} & \multirow{3}{*}{$\begin{array}{c}\text { Primary } \\
\text { result } \\
\text { of } \\
\text { NFPS }^{b}\end{array}$} & \multirow{3}{*}{$\begin{array}{c}\text { Central } \\
\text { govern- } \\
\text { ment } \\
\text { non- } \\
\text { financial } \\
\text { expen- } \\
\text { diture }\end{array}$} \\
\hline & \multicolumn{3}{|c|}{ Of central government } & \multirow{2}{*}{$\begin{array}{c}\text { Of } \\
\text { NFPS }\end{array}$} & \multirow[b]{2}{*}{$\begin{array}{l}\text { Without } \\
\text { interest } \\
\text { of NFPS }\end{array}$} & & & & & & \\
\hline & Income & $\begin{array}{c}\text { Expen- } \\
\text { diture }\end{array}$ & Saving & & & $\begin{array}{c}\text { Public } \\
\text { invest- } \\
\text { ment }\end{array}$ & $\begin{array}{r}\text { Total } \\
\text { NFPS }\end{array}$ & & & & \\
\hline 1991 & 9.5 & 9.6 & -0.1 & 1.0 & 4.4 & 2.7 & 3.8 & 0.7 & 0.1 & 0.8 & 10.0 \\
\hline 1992 & 11.4 & 11.6 & -0.3 & 1.1 & 5.1 & 3.1 & 4.2 & 0.9 & 0.4 & 1.3 & 10.0 \\
\hline 1993 & 11.3 & 11.1 & 0.2 & 1.9 & 5.5 & 3.4 & 4.4 & 1.1 & 0.4 & 1.5 & 10.7 \\
\hline 1994 & 12.9 & 12.2 & 0.7 & 2.7 & 6.1 & 3.9 & 5.1 & 1.0 & 4.5 & 5.5 & 12.7 \\
\hline 1995 & 13.6 & 13.2 & 0.4 & 2.1 & 5.3 & 4.0 & 5.0 & 0.3 & 1.6 & 1.9 & 13.8 \\
\hline 1996 & 14.2 & 12.7 & 1.6 & 3.4 & 5.7 & 3.8 & 4.5 & 1.2 & 0.1 & 1.3 & 13.7 \\
\hline 1997 & 14.1 & 11.8 & 2.2 & 4.4 & 6.1 & 3.8 & 4.5 & 1.6 & 0.1 & 1.7 & 13.4 \\
\hline $1998^{c}$ & 14.0 & 11.4 & 2.7 & 4.4 & 6.0 & 3.5 & 4.0 & 2.0 & 0.1 & 2.1 & 12.5 \\
\hline
\end{tabular}

Source: Banco Central de Reserva del Perú (various issues).

${ }^{\text {a }}$ Without capital income.

${ }^{\mathrm{b}}$ With capital income.

${ }^{\mathrm{c}} \mathrm{Up}$ to third quarter.

governments grouped together in the Paris Club and with the international private banks within the context of the Brady Plan. ${ }^{52}$

The plan was that the cooling down of the economy would be achieved through a strong fiscal adjustment, aided by a restrictive monetary policy. As may be seen from table 2 , however, what really happened was that the recessionary fiscal policy, whose main instrument was a cut in public investment in infrastructure, was accompanied by a big expansion in credit, which took place against the explicit wishes of the monetary authority.

The monetary policy applied in 1995-1996 could only be termed restrictive if we guide ourselves exclusively by the performance of the national-currency monetary aggregates; the main fact was that the rate of increase of the monetary base went down from $28 \%$ in 1995 to $7 \%$ in 1996 . In a dollarized economy where three-quarters of the credit and of deposits in the banking system are in foreign currency, however, this fact is only of relative importance. Thus, the total supply of credit to the private sector expanded increasingly fast, rising from $43.6 \%$ in 1995 to $49.6 \%$ in 1996, because of the larger amount of loans in foreign currency.

The commercial banks markedly increased their domestic loans in dollars with funds obtained abroad,

52 See Ugarteche, 1996 and 1997. just when the monetary authority was trying to impose credit restrictions through a sterilization policy. ${ }^{53}$ The evidence showing that the commercial banks resorted to the international capital market in order to satisfy the domestic demand for loans is conclusive. It may be seen from table 3 (the column headed "international liabilities as a percentage of foreign currency loans") that the short-term external indebtedness of the commercial banks has grown rapidly since the Mexican crisis.

The commercial banks have an incentive to carry out this kind of operations because there is an appreciable difference between the cost of these external funds and the domestic interest rate on foreign currency loans. Furthermore, domestic deposits in dollars are subject to a high compulsory reserve requirement $(45 \%)$, but external funds are exempt from this. Thus the compulsory reserve policy of the monetary authorities encourages the short-term external indebtedness of the commercial banks.

Consequently, if the local bankers believe that it is reasonable to increase their loans at a rapid rate, and if the international markets provide them with the funds to do this, this can easily set off a credit boom, since the monetary authorities do not have the means

53 I.e., by selling short-term securities to the banks and other financial institutions in order to sterilize or counteract the money issue resulting from the purchase of dollars. 
to moderate this excessive expansion in bank credit. ${ }^{54}$ This explains why the severe fiscal adjustment was accompanied in 1995-1996 with a substantial increase in credit, thus cooling down the economy without doing much to correct the trade deficit. ${ }^{55}$

The opposite phenomenon - a contraction which is not desired by the monetary authorities- is also possible, however. If the international markets suddenly cut off the funds with which they have been supplying the domestic banking system, this could give rise to a sharp contraction which would represent an enormous recessionary impulse while, at the same time, improving the trade balance through a reduction in imports. ${ }^{56}$ This is what happened in the third quarter of 1998 as a result of the Russian balance of payments crisis.

Since the outbreak of the Asian crisis in mid1997, the overall inflow of capital into the Peruvian economy has gone down markedly. However, the foreign-currency bank credit market has continued to work smoothly thanks to the continual increase in the funds obtained by the banks abroad.

In June 1998, the total short-term external debt came to US\$ 7323 million: equivalent to $70 \%$ of the foreign exchange reserves of the monetary authority or $110 \%$ if the compulsory reserves in respect of domestic foreign currency deposits are excluded. About half of this short-term external debt corresponded to the commercial banking system, while the rest basically comprised the short-term debt of large non-financial enterprises, which may nevertheless be guaranteed in one way or another by the local banks.

${ }^{54}$ Compulsory reserve requirements could be applied to the funds that the commercial banks obtain abroad, similar to the requirements in respect of domestic deposits in dollars, which would make it possible to cut down the supply of foreign-currency credit and make it more expensive. It could reasonably be argued that such a restrictive credit policy would raise the interest rates on loans in both soles and dollars, as well as the exchange rate (see Dancourt and Mendoza, 1996). Until a short while ago, the Central Bank was reluctant to impose compulsory reserve requirements of this nature, claiming that they would interfere with the free movement of capital and affect investors' confidence. In July 1998, however, the Superintendency of Banks and Insurance Companies introduced minimum liquidity requirements which carry out a function similar to these reserve requirements. 55 As a percentage of exports, the trade deficit went down from $39 \%$ in 1995 to $34 \%$ in 1996 , while the real exchange rate remained constant.

56 An important example of this direct link between credit and imports is expenditure on durable goods such as automobiles and electrical household appliances which are not produced in the country.
In September, however, the Peruvian economy was severely shaken by a heavy outflow of capital due to the cancellation or non-renewal of the shortterm credit lines that the local commercial banks had been obtaining abroad. This kind of stampede by the external creditors of local banks, which occurred for the first time during the 1990s, took place during the financial panic caused by the Russian balance of payments crisis.

This abrupt reversal in the short-term capital flows intermediated by the local commercial banks caused a heavy speculative attack on the national currency. As on previous occasions when there were strong upward pressures in the exchange market, this time also the national-currency price of the dollar shot up, together with the inter-bank local currency interest rate. The strange thing is that on this occasion there was also an appreciable rise in the inter-bank foreign-currency rate.

The Central Bank reacted to this upward pressure on the exchange rate by taking measures which had no precedent in recent years. Its first reaction was to intervene in the foreign exchange market through the sale of dollars, which it had not done since the auto-coup in April 1992. Its second reaction was to grant "liquidity credits" (short-term loans) in foreign currency to the commercial banks so that the latter could pay their short-term debts with the exterior, thus acting in practice as lender of last resort. It also reduced the average compulsory reserve rate on the dollar deposits of the commercial banks three times in succession, likewise so that the banks could pay their short-term debts.

Finally, the Central Bank, the Superintendency of Banks and Insurance Companies and the government itself took two more much less orthodox measures to check the rise in the exchange rate. On the one hand, they ordered the conversion of the public sector's foreign currency bank deposits into local currency: a kind of forced de-dollarization of the public sector. These deposits represented about a quarter of total deposits. On the other hand, the "overbuying" of dollars by the banks and other financial institutions was restricted to an amount equivalent to their effective net worth.

The September 1998 panic seems to have ushered in a new period of scarcity of domestic credit in foreign currency. According to the President of the Bankers' Association, the lower availability and higher cost of external credit lines will affect mortgages, 
loans for the acquisition of motor vehicles, credit cards and consumer credits (Gestión, 1998). And everything seems to indicate that this severe restriction of foreign currency credit could have a heavy negative impact on sales of consumer durables, imports, the con- struction industry and the prices of houses and land, as well as threatening the stability of the local banking system. If anything is clear at all, it is that the constant expansion of credit was the elixir that kept the Peruvian economy going in recent years.

\section{VII}

\section{By way of conclusion}

In Peru, the neoliberal strategy consists of returning to the development model based on primary commodity exports. This venture, which seeks to reinvent the 1950s in the late 1990s, is naturally faced with various obstacles.

The first obstacle is of what we might call a socio-political nature. Even if it is accepted that the structural reforms made by Fujimori can successfully restore the primary export model that prevailed during the period from 1950 to 1960 , it is necessary to take account of the conflict that the high degree of urbanization has introduced between the present social structure and the primary-export strategy.

Seminario (1995) stressed this contradiction, noting that the starting point for this last liberal attempt is a novel feature of this economic experiment: i.e., the fact that Peru is now an essentially urban economy. In the past, export economies were constructed on the basis of a mainly rural population, a great abundance of natural resources compared with the population, and a scanty level of industrial development. According to the population censuses, however, the share of the urban population in the population as a whole has risen from 35\% in 1940 to $70 \%$ in 1993.

It is hard for an economy based on the export of minerals to generate sufficient jobs in an urbanized society, as the Peruvian experience shows. This means that unemployment, whether disguised or not, will be one of the crucial economic and social problems. Consequently, there will be political pressure to develop economic activities to solve this problem. As Schydlowsky (1995) has argued, this was one of the factors that led to industrialization and protectionism.

In order to obtain a more diversified production apparatus, it would be necessary to strengthen the situation of domestic industry exposed to international competition and to promote non-traditional exports (including tourism). This involves reversing the trade openness process to some extent and also correcting the exchange-rate over-valuation. It also probably means that the Peruvian economy should be firmly integrated into the Andean Community in order to thus obtain preferential access to a large market.

The exchange-rate appreciation already mentioned would appear to represent an incoherent element, because the neoliberal reforms advocate a strategy of proexport growth. However, a low real exchange rate is only incompatible with the development of industrial exports or, perhaps, of Chilean-style agroindustrial exports, or large-scale tourism. It is not necessarily incompatible with the commodity exports which have marked the whole of Peru's economic history. It all depends on the quality of the existing natural resources and the available technology.

In reality, the problem could be posed in exactly opposite terms. If we rule out major changes in the level of economic activity or the propensity to import, the only means of securing the medium-term sustainability of this real exchange rate, which is associated with a trade deficit equal to over $30 \%$ of the values exported in the last three years, is a big expansion in these traditional exports. The question, then, is first to determine if sufficient investment projects have been put into effect in this traditional export area (especially in the mining sector) and second, if those projects will come on stream in a timely manner: that is to say, before there is a decline in the inflow of external capital, which finances the trade deficit and the net payments in respect of the public external debt and which supports this overvalued real exchange rate.

This is obviously a fragile or vulnerable situation. Adverse external shocks which reduce the inflow of foreign capital or lead to a drop in commodity prices and put back the maturity of the 
investment projects underway could give rise to a balance of payments crisis if macroeconomic policy does not respond appropriately. (An essential component in the crisis which occurred in 1975 under the Velasco Alvarado military government was the delay in the entry into operation of two big mining and petroleum projects).

Since mid-1997, as on so many other occasions in its history, the Peruvian economy has been suffering the impact of an appreciable adverse external shock which simultaneously affects both the current account and the capital account of the balance of payments. Export commodity prices have gone down markedly since the onset of the Asian crisis in mid-1997, causing a sharp drop in the terms of trade, even though the dollar price index of imports has also gone down.

At the same time, the overall inflow of capital has gone down markedly since 1997 . This paralyzation of the inflow of external capital has extended not only to long-term capital (direct investment connected with privatization operations or mega-projects in the mining sector, which were to significantly expand the production capacity of the export sector) but also to short-term capital inflows (external indebtedness of the commercial banks) since mid-1998.
What are the most suitable macroeconomic policies for dealing with an unfavourable international economic situation? This question brings us to the other important obstacle facing the neoliberal strategy, which we might call the macroeconomic obstacle. The central hypothesis of this article is that the Peruvian economy of the 1990s lacks an operative form of macroeconomic regulation which could act without giving rise to serious disturbances in the level of economic activity.

In particular, it has become clear that the monetary authorities do not possess the basic instruments that have normally been used for coping relatively successfully with the adverse external shocks to which a small open economy is inevitably exposed. Monetary policy has lost its effectiveness as a result of two structural reforms which have been made in the financial field: the dollarization of the banking system and the opening up of the capital account.

Overcoming the first obstacle amounts to changing the primary export model, perhaps so much as to make it unrecognizable. Overcoming the second obstacle is an urgent task, but perhaps somewhat less complicated.

(Original: Spanish)

\section{Bibliography}

Banco Central de Reserva del Perú (BCRP) (various issues): Nota semanal, Lima.

-(1995): Memoria 1994, Lima.

(1996): Perú: compendio de estadísticas monetarias 1959-1995, Lima.

-(1998): Memoria 1997, Lima.

Borricaud, F. (1989): Poder y sociedad en el Perú, Lima, Instituto de Estudios Peruanos.

Calvo, G., L. Leiderman and C. Reinhart (1993): Capital inflows and real exchange rate appreciation in Latin America, Staff Papers, vol. 40, No. 1, Washington, D.C., International Monetary Fund (IMF).

Cline, W. (1981): Economic stabilization in Peru, 19751978, in W. Cline and S. Weintraub (eds.), Economic Stabilization in Developing Countries, Washington, D. C., The Brookings Institution.

Cotler, J. (1994): Política y sociedad en el Perú: cambio y continuidades, Perú problema, No. 3, Lima, Instituto de Estudios Peruanos.

Dancourt, O. (1996): Estabilización y deuda externa en el Perú: experiencia y perspectivas, in G. Portocarrero and M. Valcarcel (eds.), El Perú frente al siglo
XXI, Lima, Pontificia Universidad Católica del Perú (PUCP).

Dancourt, O. and W. Mendoza (1996): Flujos de capital, política monetaria y equilibrio externo, Documento de trabajo, No. 126, Lima, PUCP, Departamento de Economía.

Dancourt, O., W. Mendoza and L. Vilcapoma (1997): Fluctuaciones económicas y shocks externos, Perú 1950-1996, Documento de trabajo, No. 135, Lima, PUCP, Departamento de Economía.

Fairlie, A. (1996): Comunidad Andina, regionalismo abierto y comercio intraindustrial, in El Protocolo de Trujillo y la Comunidad Andina, Política internacional, No. 43, Lima, Academia Diplomática del Perú.

Ferrari, C. (1992): Industrialización y desarrollo: politicas y efectos económicos en el Perú, Lima, Friedrich Ebert Foundation.

Figueroa, A. (1993): Crisis distributiva en el Perú, Lima, PUCP.

Fitzgerald, E. V. K. (1985): Capitalismo de Estado en el Perú: limitaciones de un modelo de desarrollo 
económico, El gobierno militar: una experiencia peruana 1968-1980, Lima, Instituto de Estudios Peruanos.

Frenkel, R., J.M. Fanelli and G. Rozenwurcel (1993): Growth and Structural Reform in Latin America. Where We Stand, Discussion Papers, No. 62, Geneva, United Nations Conference on Trade and Development (UNCTAD).

Gavin, M., R. Hausmann, R. Perotti and E. Talvi (1996): Managing Fiscal Policy in Latin America and the Caribbean. Volatility, Procyclicality, and Limited Creditworthiness, Working Paper series, No. 326, Washington, D. C., Inter-American Development Bank (IDB).

Gestión (1998): Issue dated 12 October 1998, Lima.

González, E. (1994): Ajuste estructural y reforma de la economía fiscal en el Perú, Documentos de Trabajo series, No. 64, Lima, Instituto de Estudios Peruanos.

Hofman, A. (1993): Economic development in Latin America in the 20th century. A comparative perspective, in A. Szirmai, B. Van Ark and D. Pilat (eds.), Explaining Economic Growth. Essays in Honour of Angus Maddison, Amsterdam, The Netherlands, North-Holland.

Hunt, S. (1996): Peru: The current economic situation in long-term perspective, in E. Gonzales de Olarte (ed.), The Peruvian Economy and Structural Adjustment: Past, Present, and Future, Miami, Florida, University of Miami, North-South Center Press.

Iguíniz, J. (1986): La crisis peruana actual: un esquema para una interpretación, in H. Bonilla (ed.), Las crisis económicas en la historia del Perú, Lima, Centro Latinoamericano de Historia Económica y Social/ Friedrich Ebert Foundation.

Jiménez, F. (1991): Acumulación y ciclos en la economía peruana: crisis de paradigmas y estrategia de desarrollo neoliberal, Lima, Centro de Estudios para el Desarrollo y la Participación (CEDEP).

- (1996): Notas sobre la desindustrialización reciente y la necesidad de una nueva política industrial, Socialismo y participación, No. 74, Lima, CEDEP.

Krugman, P. (1988): External shocks and domestic policy responses, in R. Dornbusch and F.I. Helmers (eds.), Open Economy. Tools for Policymakers in Developing Countries, Washington, D.C., Oxford University Press.

Krugman, P. and L. Taylor (1978): Contractionary effects of devaluation, Journal of International Economics, vol. 8, No. 3, Amsterdam, The Netherlands, NorthHolland Publishing Company.

Maddison, A. (1991): Dynamic Forces in Capitalist Development: A Long Run Comparative View, Oxford, U.K., Oxford University Press.

-(1992): La economía mundial en el siglo XX. Rendimiento y política en Asía, América Latina, la
URSS y los países de la OCDE, Mexico City, Fondo de Cultura Económica (FCE).

Marfán, M. and B. Bosworth (1994): Saving, investment, and economic growth, in B. Bosworth, R. Dornbusch and R. Labán (eds.), The Chilean Economy. Policy Lessons and Challenges, Washington, D.C., The Brookings Institution.

Paredes, C. and J. Sachs (eds.)(1990): Estabilización y crecimiento en el Perú, Lima, Grupo de Análisis para el Desarrollo (GRADE).

Robles, M. (1996): Los ciclos económicos en el Perú: 1950-1995, Lima, Instituto Nacional de Estadística e Informática.

Rojas, J. (1996): Políticas comerciales y cambiarias en el Perú, 1960-1995, Lima, PUCP.

Rojas, J. and L. Vilcapoma (1996): Algunas características importantes de la nueva Banca Peruana: un estudio preliminar, Documento de trabajo, No. 124, Lima, PUCP, Departamento de Economía.

Rossini, R. (1991): Liberalización comercial y estabilización económica, Foro económico liberalización del comercio exterior, Lima, Friedrich Ebert Foundation.

Ruiz, G. (1995): Apreciación cambiaria, política monetaria y afluencia de capitales: Perú 1990-1994, Economía, vol. XVIII, Nos. 35-36, Lima, PUCP, Departamento de Economía.

Schuldt, J. (1994): La enfermedad holandesa y otros virus de la economía peruana, Documento de trabajo, No. 20, Lima, Universidad del Pacífico, Centro de Investigación.

Schydlowsky, D. (1986): The macroeconomic effect of nontraditional exports in Peru, Economic Development and Cultural Change, vol. 34, No. 3, Chicago, Illinois, The University of Chicago Press.

-(1995): La recuperación económica peruana en contexto histórico, Lima, mimeo.

Schydlowsky, D. and J. Wicht (1979): Anatomía de un fracaso económico: Perú 1968-1978, Lima, Universidad del Pacífico, Centro de Investigación.

Seminario, B. (1995): Reformas estructurales y políticas de estabilización, Documento de trabajo, No. 22, Lima, Universidad del Pacífico, Centro de Investigación.

Seminario, B. and C. Boullon (1992): Ciclos y tendencias en la economía peruana: 1950-1989, Cuadernos de investigación, No. 15, Lima, Universidad del Pacífico, Centro de Investigación.

Taylor, L. (1991): Economic openness: Problem to the century's end, in T. Banori (ed.), Economic Liberalization: No Panacea, Oxford, U. K., Oxford University Press.

Terrones, M. and C. Calderón (1993): El ciclo económico en el Perú, Documentos de trabajo, No. 20, Lima, GRADE. 
Thorp, R. (1995): Gestión económica y desarrollo en Perú y Colombia, Lima, Universidad del Pacífico.

-(1996): A Long-Run Perspective on Short-Run Stabilization, in E. Gonzales de Olarte (ed.), The Peruvian Economy and Structural Adjustment: Past, Present, and Future, Miami, Florida, University of Miami, North-South Center Press.

Thorp, R. and G. Bertram (1978): Peru 1890-1977: Growth and Policy in an Open Economy, New York, Columbia University Press.

Ugarteche, O. (1996): La deuda peruana a fines de siglo, Lima, CEDEP.

- (1997): Deuda externa: el fin de la historia, Revista actualidad económica, No. 175, Lima, Centro de Asesoría Laboral del Perú (CEDAL).
Vega, J. (1997): Foreign trade policy and economic integration policy in Peru: Analysis of a dilemma, in A.J. Jatar and S. Weintraub (eds.), Integrating the Hemisphere, Washington, D.C., Inter-American Dialogue Conference.

Vega-Centeno, M. (1989): Inversiones y cambio técnico en el crecimiento de la economía peruana, Economía, vol. XII, No. 24, Lima, PUCP, Departamento de Economía.

Vilcapoma, L. (1996): Fluctuaciones macroeconómicas en la economía peruana: 1950-1990, Documento de trabajo, No. 130, Lima, PUCP, Departamento de Economía. 